\title{
Cutaneous fistula due to remaining foreign bodies after penetrating neck injury
}

\author{
W M P F Bosman, E D Ritchie, S A da Costa
}

Department of Surgery, Rijnland Ziekenhuis, Leiderdorp, The Netherlands

Correspondence to Dr E D Ritchie, e.ritchie@rijnland.nl
To cite: Bosman WMPF, Ritchie ED, da Costa SA. BMJ Case Rep Published online: [please include Day Month Year] doi:10.1136/ bcr-2013-201278

\section{DESCRIPTION}

A car which was driving backwards on a parking place hit a 56-year-old female motorcyclist and she was launched through the rear windshield of the car. On admittance at the emergency department, the patient was assessed and treated following the Advanced Trauma Life Support protocol. ${ }^{1}$ The patient was haemodynamic and respiratory stable on primary survey. Secondary survey showed a lateral tibial plateau fracture in anatomical position, several small lacerations on the right side of the face and a large cut wound dorsal of the right ear, extending to the cranial part of the sternocleidomastoid muscle. The tibial plateau fracture was treated conservatively with a stiff brace, while the wounds were explored on the emergency department and closed with sutures after the macroscopic removal of shattered glass pieces from the broken windshield.

Six weeks after the initial trauma, the wound dorsal of the ear remained painful and a fistula persisted, which produced unclear discharge. A CT-scan showed the presence of glass splinters, protruding the sternocleidomastoid muscle up to the spinous process of the third cervical body (figure 1).

In the operating room, the scar tissue was resected, and the area dorsocaudal of the right ear was explored. Subcutaneous tissue behind the sternocleidomastoid muscle was infiltrated and was infested with glass splinters (figure 2A). In total, more than 50 pieces of glass were removed (figure 2B). There were no neurovascular structures at risk due to the foreign bodies. Postoperative recovery was without complications.

Penetrating neck injury is a serious condition with high morbidity and potential mortality. ${ }^{2}$ Owing to a low incidence of penetrating neck injuries in the average European hospital, there is no large experience with the management. Van Waes et $a l^{2}$ advise a selective non-operative management with, if indicated, a CT angiography and/or endoscopy if the patient is haemodynamically stable and explorative surgery in case of shock.

In the current case, the degree of penetration of the foreign bodies was not recognised on the emergency department by the surgical registrar on call, probably due to the fact that the patient was haemodynamically stable and no vital structures were damaged. This led to suturing of the wound with many splinters still in-situ. The amount of discharge from the cutaneous fistula and mechanic symptoms were indications for surgical exploration and debridement in the operating theatre. Routine surgical neck exploration
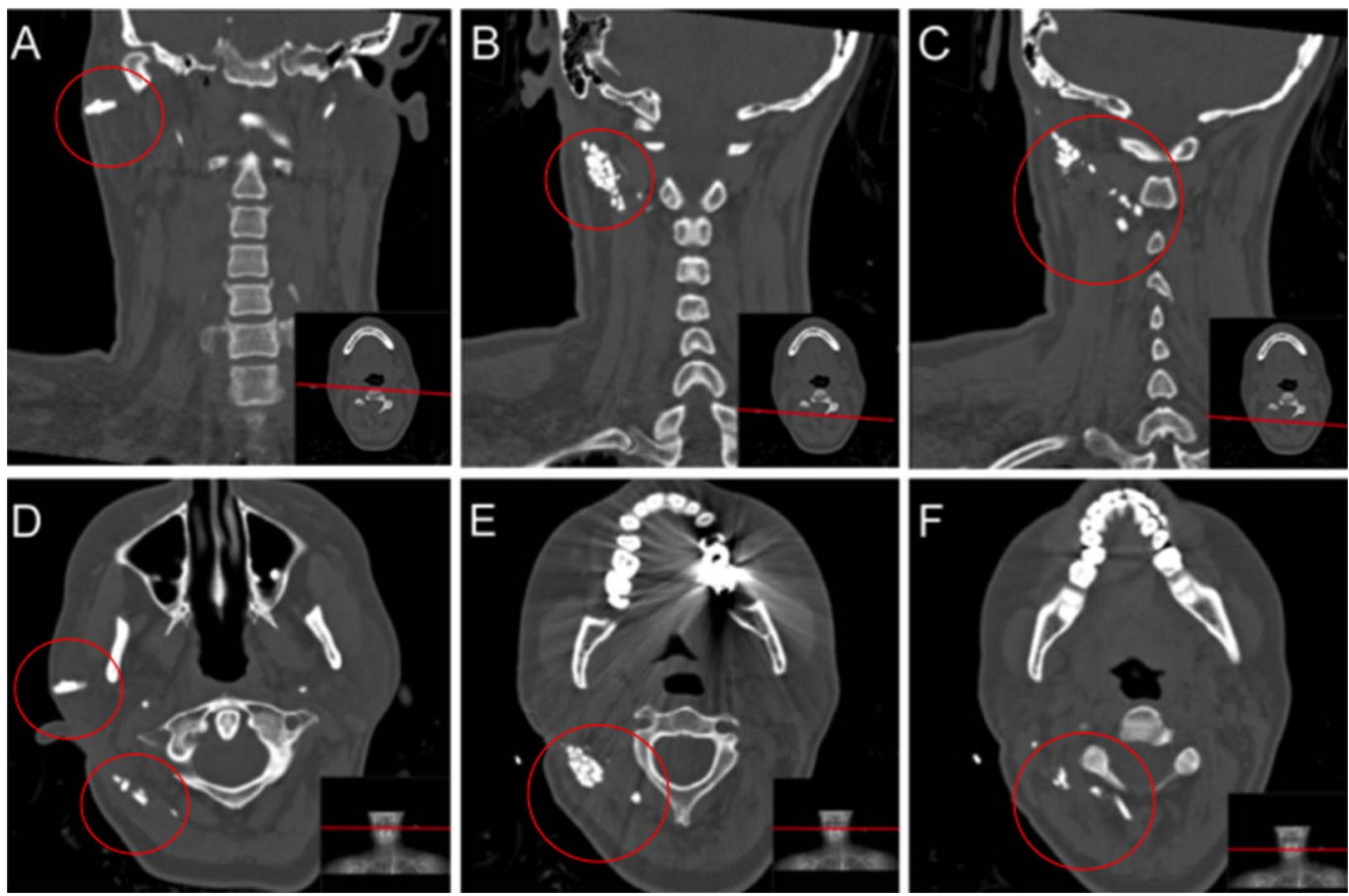

Figure 1 Overview of preoperative CT scan ((A-C) coronal views, (D-F) transversal views). Red circles show the remaining foreign bodies, leading up to spinous body of the cervical bodies. 


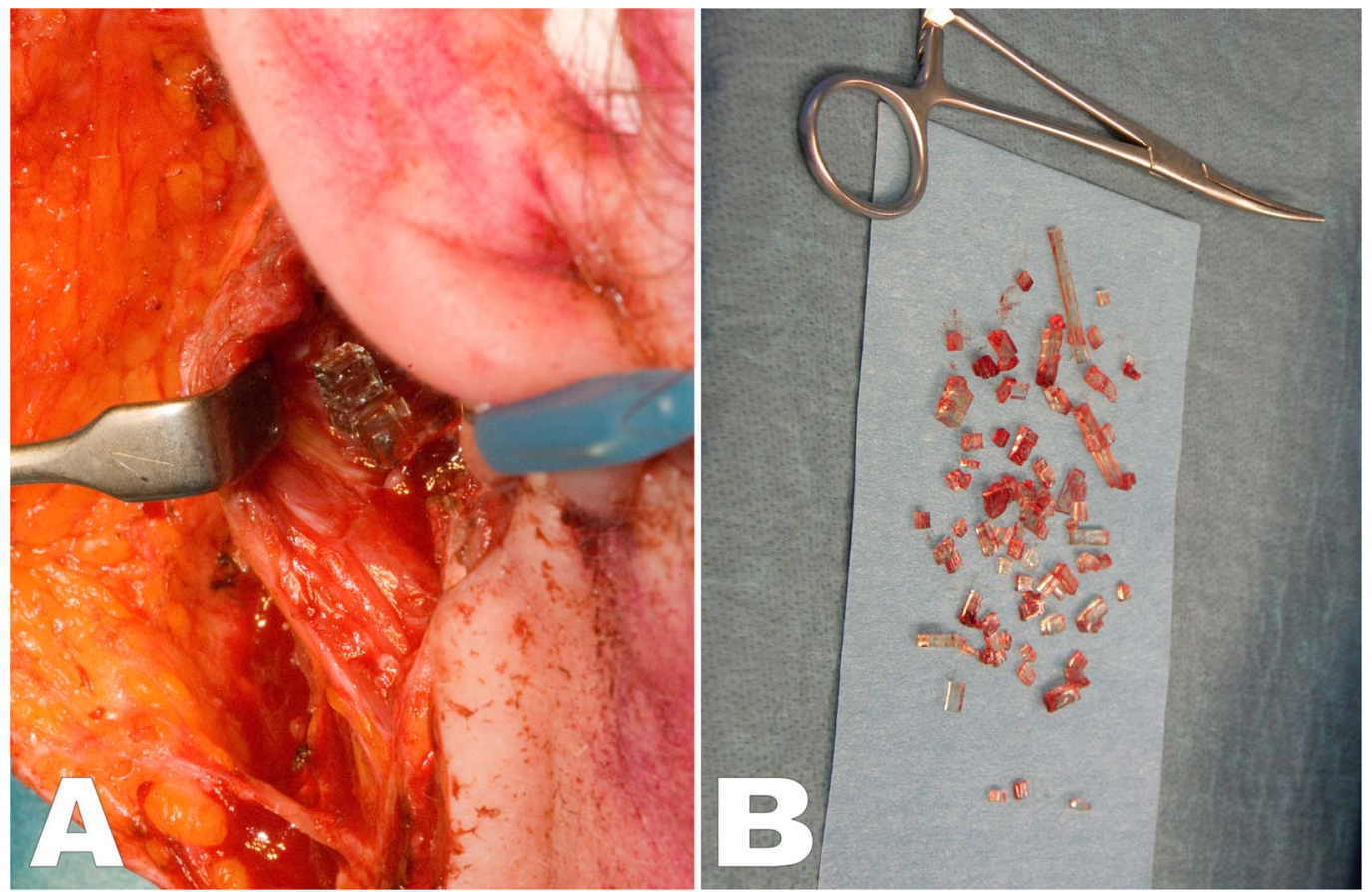

Figure 2 Surgical exploration showed a large amount of glass splinters under the sternocleidomastoid muscle (A). In total, over 50 pieces of glass were removed from the patients neck $(B)$.

after penetrating injury is not recommended as it may be unnecessary, with a high risk of iatrogenic injuries. ${ }^{2}$

\section{Learning points}

- In case of penetrating neck injuries, be suspicious of remaining foreign bodies.

- Non-invasive imaging (eg, CT angiography) is of additional value in case of penetrating neck injury.

- In case of cutaneous fistula/wound discharge after penetrating injury, the presence of remaining foreign bodies should be excluded by performing imaging (eg, ultrasound, (T)
Contributors WMPFB was involved in drafting, writing, literature search and was the treating physician for the patient. EDR was involved in critical review and literature search. SAdC was involved in critical review of the manuscript and was the treating physician for the patient.

Competing interests None.

Patient consent Obtained.

Provenance and peer review Not commissioned; externally peer reviewed.

\section{REFERENCES}

1 Carmont MR. The Advanced Trauma Life Support course: a history of its development and review of related literature. Postgrad Med J 2005:81:87-91.

2 Van Waes OJ, Cheriex KCAL, Navsaria PH, et al. Management of penetrating neck injuries. Br J Surg 2011;99(S1):149-54.

Copyright 2013 BMJ Publishing Group. All rights reserved. For permission to reuse any of this content visit http://group.bmj.com/group/rights-licensing/permissions.

BMJ Case Report Fellows may re-use this article for personal use and teaching without any further permission.

Become a Fellow of BMJ Case Reports today and you can:

- Submit as many cases as you like

- Enjoy fast sympathetic peer review and rapid publication of accepted articles

- Access all the published articles

- Re-use any of the published material for personal use and teaching without further permission

For information on Institutional Fellowships contact consortiasales@bmjgroup.com

Visit casereports.bmj.com for more articles like this and to become a Fellow 